\title{
Perbedaan Kemampuan Motorik Ibu dalam Mencegah Regurgitasi pada Bayi Usia 0- 3 bulan Sebelum dan Sesudah Pendidikan Kesehatan (Latihan) Menyendawakan
}

\author{
Triatmi Andri Yanuarini ${ }^{1}$, Sumy Dwi Antono ${ }^{2}$, Septia Wulandari \\ ${ }^{1,2}$ Dosen Poltekkes Kemenkes Malang Prodi Kebidanan Kediri
}

\begin{abstract}
According to the Indonesian Demographic and Health Survey (SDKI) in 2012, The infant mortality rate was 31,41 by 1,000 live births occured in the first month of life. Result of the interview on four people at work area Ngadiluwih public health center at Kediri Regency, indicating lack of knowladge and attitude towards regurgitation. Therefore, acces to health emphasis on nutritional conseling, how to be parents and accident prevention help reduce the infant mortality rate. The research was conducted on 23 June to 8 July 2014 aimed to determain Differences in motor skills in preventing regurgitation mothers to infants aged 0-3 months before and after health education (training) burping (analityc studies at work area Ngadiluwih public health center at Kediri Regency). Statistical analysis with the wilcoxon test found that the value of count equal to $5,301>\mathrm{z}$ table $(1,96)$ then $\mathrm{H} 0$ is rejected and $\mathrm{H} 1$ is accepted which means there is the Differences in motor skills in preventing regurgitation mothers to infants aged 0-3 months before and after health education (training) burping (analityc studies at work area Ngadiluwih public health center at Kediri Regency).
\end{abstract}

Keywords: Regurgitation, IMR, Suddent Infant Death Syndrom

\section{Pendahuluan}

Saat ini Angka kematian Bayi di Indonesia masih tinggi. Menurut survei Demografi dan Kesehatan Indonesia (SDKI) tahun 2012 Angka Kematian Bayi tahun 2009 sebesar 31,41 per 1.000 kelahiran hidup; tahun 2011 mencapai 29,24 per 1.000 kelahiran hidup; dan di tahun 2012 mencapai 28,31 per 1.000 kelahiran hidup. Dalam kurun waktu dua tahun ke depan diharapkan mencapai target MDGs yaitu 23 per 1.000 kelahiran hidup pada tahun 2015.

Berdasarkan Profil Kesehatan Provinsi Jawa Timur 2012, Angka kematian Bayi di Jawa Timur bervariasi dari yang paling rendah, yaitu 19,50 per 1.000 kelahiran hidup di Kota Blitar, 21,88 per 1.000 kelahiran hidup di Kabupaten Trenggalek sampai yang paling tinggi 63,51 per 1.000 kelahiran hidup di Kabupaten Probolinggo. Beberapa penelitian telah menunjukan bahwa lebih dari $50 \%$ kematian bayi terjadi dalam periode neonatal yaitu dalam bulan pertama kehidupan. Mereka mengaitkan tingginya angka kematian bayi ini dengan terbatasnya pendidikan ibu, usia ibu yang masih muda, kemiskinan dan kurangnya perawatan prenatal. Selain itu penelitian oleh EPICure Amerika Serikat tahun 2000 menunjukan bahwa enam puluh persen dari semua kematian bayi terjadi pada $7,6 \%$ bayi dengan berat badan lahir rendah, $2 \%$ karena asfiksia perinatal, 2,5\% karena infeksi dan 8\% karena sindrom kematian bayi mendadak (SIDS) (Lissauer Tom, 2009).

Sindrom kematian bayi mendadak merupakan salah satu penyebab terbesar dari kematian bayi di bawah 1 tahun, dan sebagian besarnya adalah bayi berusia 2- 4 bulan. Penyebab yang pasti dari sindrom ini belum dimengerti. Sejumlah korban dengan sindrom kematian bayi mendadak mengalami apnea sebelum kematian. Apnea yang berkepanjangan dapat menyebabkan bayi tersedak atau tersumbat dan berhentinya napas (National Safety Council, 2007). Oleh karena itu akses ke program perawatan kesehatan yang menekankan pada 
penyuluhan gizi dan pemberian dukungan, penyuluhan kesehatan dan penyuluhan cara menjadi orang tua, program imunisasi, dan penyuluhan tentang pencegahan kecelakaan dapt membantu mengurangi angka kematian bayi (Bobak, 2005).

Pada dasarnya, setiap asuhan bayi memerlukan keterlibatan orang tua mencakup keterampilan dan pengetahuan dalam perawatan bayi. Bagi banyak ibu dan bayi, menyususi terjadi secara langsung dan naluriah. Hal tersebut akan lebih baik bila setelah proses menyusui selesai, seorang ibu mempunyai sikap yang baik dalam menyendawakan. Pada saat lahir kapasitas lambung bayi adalah sekitar 1 sampai 2 ounces (30 sampai 60 ml) dan meningkat dengan cepat. Karena bayi menghisap puting, udara mungkin akan terhisap. Hal ini menimbulkan rasa kenyang yang palsu karena lambung penuh. Bila bayi tidak diangkat ke atas sampai posisi kepalanya tegak sehingga udara tidak dapat keluar dengan bersendawa, udara akan tetap dalam lambung selama beberapa waktu. Hal ini akan mendorong susu keluar bersamanya atau terjadi regurgitasi (Hamilton, Persis Mary, 2011). Regurgitasi adalah kembalinya sejumlah makanan yang belum dicerna dari lambung, biasanya disertai sendawa (Wong, 2008). Regurgitasi ini cukup sering terjadi pada bayi akibat perkembangan sfingter esophagus bawah yang tidak sempurna (Price, Sylvia Anderson, 2005).

Dengan bersendawa udara dalam saluran makanan yang menyesakkan dapat dikeluarkan kembali. Ada juga bayi yang harus berhenti sebentar selagi minum untuk bersendawa agar udara yang terikut masuk dapat keluar dan proses menyusu tidak terganggu(Ieneke, S, 2002). Ibu yang melewatkan untuk menyendawakan bayinya setelah disusui, tentu saja bukan karena faktor kelalaian, melainkan karena faktor ketidaktahuan (Hidayat Aziz, 2005).
Meskipun normal, regurgitasi yang berlebihan dapat menyebabkan berbagai komplikasi yang akan mengganggu pertumbuhan bayi apabila terjadinya tidak hanya setelah makan dan minum saja. Data dari beberapa negara termasuk Indonesia memperlihatkan sekitar $70 \%$ bayi berumur di bawah 4 bulan mengalami regurgitasi minimal satu kali setiap harinya. Begitu juga penelitian yang dilakukan di RSCM tahun 2004 menemukan bahwa bayi yang mengalami regurgitasi lebih dari 4 kali sehari mengalami kenaikan berat badan yang lebih rendah pada 4 bulan pertama usia bayi (IDAI, 2009). Penelitian dengan judul Hubungan Tingkat Pendidikan dengan Pengetahuan Buteki Bayi usia 0-6 bulan tentang Regurgitasi di Desa Paron Wilayah Kerja Puskesmas Ngasem Kabupaten Kediri dengan hasil $90 \%$ bayi sering mengalami regurgitasi dan ibu tidak mengetahui cara untuk mengurangi frekuensi regurgitasi.

Meskipun regurgitasi tidak membahayakan, namun pada keadaan tertentu harus diwaspadai oleh ibu. Seperti apabila regurgitasi berlangsung terus menerus atau terlalu sering biasanya disebabkan oleh gangguan dalam saluran pencernaan. Akibatnya bayi dapat kehilangan cairan tubuh atau dehidrasi (Maryuani Anik, 2010).

Studi pendahuluan yang telah dilakukan oleh peneliti di Wilayah Kerja Puskesmas Ngadiluwih pada tanggal 2728 Februari 2014 di peroleh data dari bidan desa Branggahan, Tales dan Bangle terdapat 43 ibu yang menyusui bayinya dengan usia bayi 0- 3 bulan. Dari hasil wawancara yang dilakukan pada 4 orang ibu menyusui, ketika ditanyakan tentang pengetahuan dan sikap mereka tentang penyebab regurgitasi mereka memiliki pengetahuan dan sikap yang kurang terhadap regurgitasi. Ibu juga mengatakan bahwa mereka belum pernah mendapatkan penyuluhan tentang regurgitasi sebelumnya. 
Dari latar belakang di atas peneliti tertarik untuk mengadakan penelitian tentang perbedaan kemampuan motorik ibu dalam mencegah regurgitasi pada bayi usia 0-3 bulan sebelum dan sesudah pendidikan kesehatan (latihan) menyendawakan di Wilayah Kerja Puskesmas Ngadiluwih Kabupaten Kediri

\section{Metode Penelitian}

Jenis penelitian yang digunakan adalah analitik komparatif dengan menggunakan Pre-Experimental Design dan desain penelitian One Group PretestPost Test Design dimana sudah dilakukan observasi pertama (Pretest) yang memungkinkan menguji perubahanperubahan yang terjadi setelah adanya eksperimen (program) (Notoatmodjo, S. 2010). Peneliti melakukan pengukuran terhadap kemampuan motorik ibu dalam mencegah regurgitasi pada bayi usia 0-3 bulan sebelum diberikan pelatihan menyendawakan dan setelah diberikan pelatihan menyendawakan selama 30 menit. Populasi dalam penelitian ini adalah seluruh ibu menyusui di Desa Branggahan, Tales, Bangle dengan bayi usia 0-3 bulan Wilayah Kerja Puskesmas Ngadiluwih Kabupaten Kediri pada bulan Juni- Juli 2014 sejumlah 43 orang. Sampel dalam penelitian ini adalah sebagian ibu menyusui di desa Branggahan, Tales, Bangle dengan bayi usia 0-3 bulan Wilayah Kerja Puskesmas Ngadiluwih Kabupaten Kediri sejumlah 39 orang. Tehnik sampling yang digunakan cluster random sampling. Analisa data menggunakan Wilcoxon Match Pairs, test signifikasi $5 \%$.

\section{Hasil penelitian}

Pada hasil penelitian ini, data yang akan disajikan diantaranya terdiri dari data umum dan data khusus. Data umum menggambarkan karakteristik ibu menyusui yang terdiri dari usia, pendidikan, dan pekerjaan. Sedangkan data khusus menggambarkan variabelvariabel yang ada dalam penelitian antara lain kemampuan motorik ibu dalam mencegah regurgitasi sebelum diberikan pelatihan menyendawakan, sesudah pelatihan menyendawakan.

Data Umum

a. Karakteristik Responden Berdasarkan Usia :

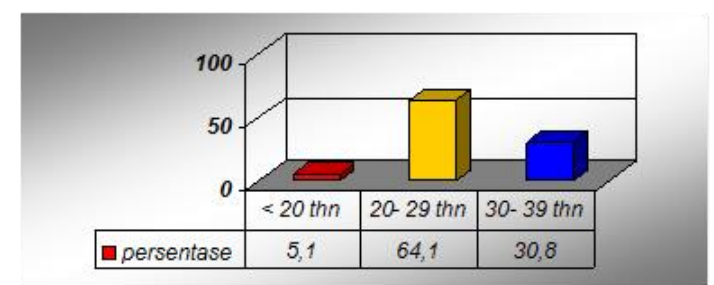

Diagram 1 Distribusi frekuensi responden berdasarkan usia pada ibu menyusui bayi usia 0-3 bulan di Wilayah Kerja Puskesmas Ngadiluwih Kabupaten Kediri

Berdasarkan diagram 1 dapat diketahui bahwa dari hasil penelitian didapatkan sebagian besar responden berusia 20-29 tahun, yaitu sejumlah 23 responden $(62,1 \%)$, usia $30-39$ tahun sejumlah 12 responden $(32,4 \%)$ dan 2 responden berusia $<20$ tahun $(5,4 \%)$.

b. Karakteristik Responden Berdasarkan Pekerjaan

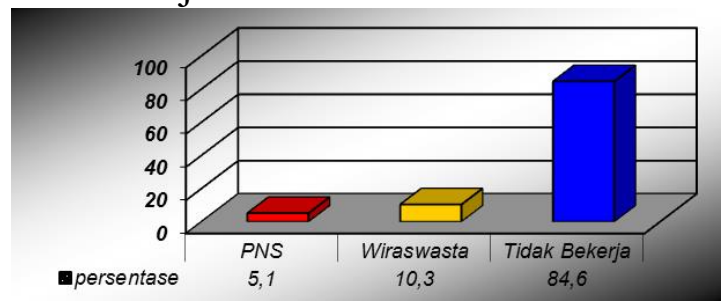

Diagram 2 Distribusi frekuensi responden berdasarkan pekerjaan pada ibu menyusui bayi usia 0-3 bulan di Wilayah Kerja Puskesmas Ngadiluwih Kabupaten Kediri

Berdasarkan diagram 2 dapat diketahui bahwa dari hasil penelitian didapatkan sebagian besar responden tidak bekerja, yaitu sebanyak 32 responden $(86,4 \%), 4$ responden $(10,8 \%)$ wiraswasta dan 1 responden $(2,7 \%)$ sebagai PNS. 
c. Karakteristik Responden Berdasarkan Pendidikan :

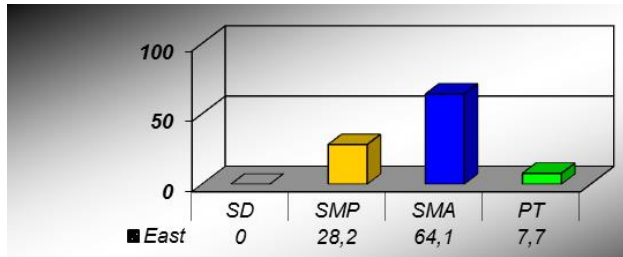

Diagram 3 Distribusi frekuensi responden berdasarkan Pendidikan pada ibu menyusui bayi usia 0-3 bulan di Wilayah Kerja Puskesmas Ngadiluwih Kabupaten Kediri

Berdasarkan tabel 3 dapat diketahui bahwa dari hasil penelitian didapatkan sebagian besar responden berpendidikan terakhir SMA, yaitu sebanyak 25 responden $(67,6 \%), 11$ responden $(29,7 \%)$ berpendidikan terakhir SMP dan 1 responden $(7,7 \%)$ Akademi atau PT.

\section{Data Khusus}

a. Kemampuan Motorik Ibu dalam Mencegah Regurgitasi sebelum Pendidikan Kesehatan (latihan) Menyendawakan :

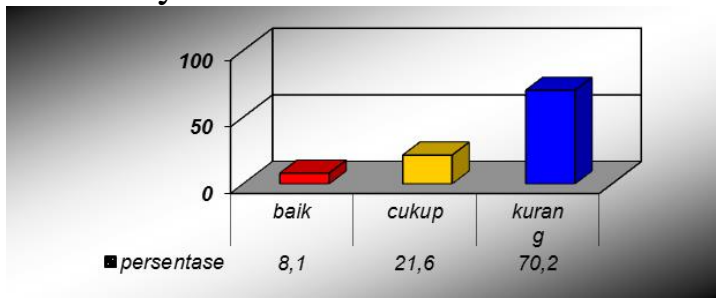

Diagram 4.4 Distribusi frekuensi responden berdasarkan kemampuan motorik ibu dalam mencegah regurgitasi pada bayi usia 0- 3 bulan sebelum pendidikan kesehatan (latihan) menyendawakan di Wil Kerja Puskesmas Ngadiluwih Kab Kediri

Berdasarkan tabel 4 dapat diketahui bahwa dari hasil penelitian didapatkan sebagian besar responden memiliki kemampuan kurang dalam mencegah regurgitasi pada bayi usia $0-3$ bulan sebelum dilakukan pelatihan menyendawakan, yaitu sebanyak 26 responden $(70,2,7 \%)$. b. Kemampuan Motorik Ibu dalam Mencegah Regurgitasi setelah Pendidikan Kesehatan (latihan) Menyendawakan :

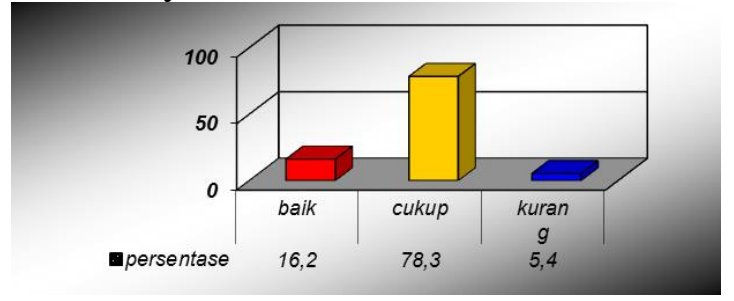

Diagram 4 Distribusi frekuensi responden berdasarkan kemampuan motorik ibu dalam mencegah regurgitasi pada bayi usia $0-3$ bulan setelah pendidikan kesehatan (latihan) menyendawakan di Wil Kerja Puskesmas Ngadiluwih Kabupaten Kediri

Berdasarkan diagram 4 dapat diketahui bahwa dari hasil penelitian didapatkan sebagian besar responden memiliki kemampuan cukup dalam mencegah regurgitasi pada bayi usia $0-3$ bulan setelah dilakukan pelatihan menyendawakan, yaitu sebanyak 29 responden $(78,3 \%)$.

c. Perbedaan Kemampuan Motorik Ibu dalam Mencegah Regurgitasi pada Bayi Usia 0- 3 Bulan Sebelum dan Sesudah Pendidikan Kesehatan (latihan) Menyendawakan di Wilayah Kerja Puskesmas Ngadiluwih Kab Kediri

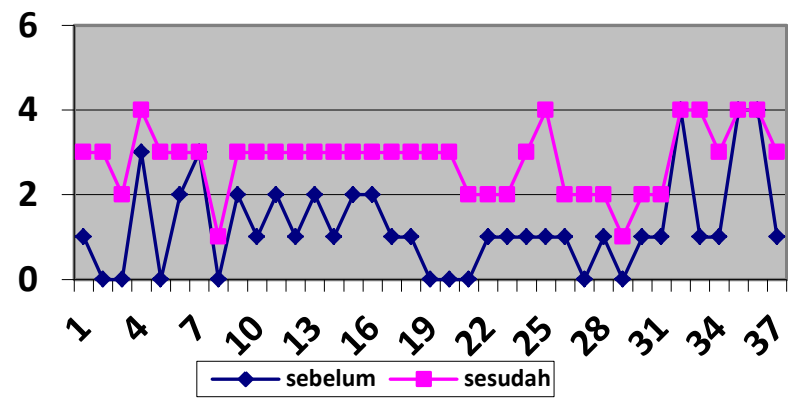

Diagram 5 Perbedaan Kemampuan motorik ibu dalam Mencegah Regurgitasi pada Bayi Usia 0- 3 Bulan Sebelum dan Sesudah diberikan Pendidikan Kesehatan (latihan) Menyendawakan di Wilayah 
Kerja Puskesmas Ngadiluwih Kab Kediri

Berdasarkan diagram 5 dapat diketahui bahwa sebagian besar dari responden yang memiliki kemampuan motorik kurang yakni dengan nilai 0-1 dalam praktik mencegah regurgitasi sebelum pendidikan kesehatan (latihan) menyendawakan menunjukkan peningkatan kemampuan menjadi kemampuan cukup dengan nilai 2- 3.

Untuk menganalisis perbedaan kemampuan motorik ibu dalam mencegah regurgitasi pada bayi usia $0-3$ bulan dilakukan uji statistik dengan Wilcoxon Test yang didapatkan nilai bahwa $\mathrm{z}$ hitung sebesar -5,302. Karena nilai absolut $\mathrm{z}$ hitung yaitu 5,302 > z tabel (1, 96) maka Ho ditolak dan H1 diterima yang berarti ada perbedaan kemampuan motorik ibu dalam mencegah regurgitasi pada bayi usia 0- 3 bulan sebelum dan sesudah diberikan pendidikan kesehatan (latihan) menyendawakan di Wilayah Kerja Puskesmas Ngadiluwih Kabupaten Kediri.

\section{Pembahasan}

Kemampuan Motorik Ibu dalam Mencegah Regurgitasi pada Bayi Usia 0-3 Bulan Sebelum diberikan Pelatihan Menyendawakan

Berdasarkan hasil penelitian, pada tabel 4 dapat diketahui bahwa sebagian besar responden memiliki kemampuan kurang dalam mencegah regurgitasi pada bayi usia 0- 3 bulan sebelum dilakukan pelatihan menyendawakan, yaitu sebanyak 26 responden $(66,7 \%)$.

Hal ini dapat dipengaruhi oleh beberapa faktor. Ditinjau dari faktor pendidikan, Notoatmodjo (2003) berpendapat bahwa pendidikan memegang peranan penting pada setiap perubahan perilaku untuk mencapai tujuan. Dengan tingginya pendidikan, diharapkan pengetahuan seseorang bertambah, sehingga memudahkan dalam menerima atau mengadopsi perilaku positif.
Dari hasil penelitian didapatkan sebagian besar responden berpendidikan terakhir SMA, yaitu sebanyak 25 responden $(67,6 \%), 11$ responden $(29,7 \%)$ berpendidikan terakhir SMP dan 1 responden $(7,7 \%)$ Akademi atau PT. Dari data tersebut menunjukan 1 orang responden dengan pendidikan terakhir PT memiliki kemampuan motorik baik dalam mencegah regurgitasi dengan menyendawakan bayi, hal ini membuktikan bahwa dengan tingginya pendidikan seseorang akan semakin tingi pula pengetahuannya.

Pendidikan merupakan salah satu faktor yang mampu mempengaruhi keterampilan seorang individu. Hal ini berbanding lurus dengan pendapat Roni Sujarwo (2012) pendidikan yang rendah akan mengakibatkan seseorang memiliki pengetahuan yang rendah. Pendidikan merupakan salah satu tempat dimana seseorang mendapat pendidikan, pelatihan dengan dibekali berbagai ilmu. Seseorang yang tidak dibekali dengan ilmu akan mengalami keterbelakangan dalam hal wawasan, cara berfikir dan bahkan keterampilan yang kurang.

Tidak hanya faktor pendidikan, pekerjaan merupakan salah satu faktor yang dapat mempengaruhi kemampuan seorang individu dalam merawat bayinya. Seperti yang dikemukakan oleh Mubarok (2011), bahwa lingkungan pekerjaan dapat membuat seseorang memperoleh pengalaman dan pengetahuan baik secara langsung maupun tidak langsung. Berdasarkan diagram 4.2 dapat diketahui bahwa dari hasil penelitian didapatkan sebagian besar responden tidak bekerja, yaitu sebanyak 33 responden $(84,6 \%), 4$ responden $(10,3 \%)$ wiraswasta dan 2 responden $(5,1 \%)$ sebagai PNS.

Hasil penelitian menunjukan bahwa responden yang berada pada kategori kemampuan motorik kurang dalam mencegah regurgitasi sebagian besar adalah ibu menyusui pada bayi usia 0-3 bulan yang tidak bekerja. Ini menunjukan bahwa lingkungan pekerjaan dan 
hubungan sosial yang terjadi didalamnya mempengaruhi seseorang dalam kemudahan memperoleh informasi terbaru, pengalaman dan pembelajaran bagi individu tersebut.

Seorang ibu yang merawat bayinya,dimana dalam penelitian ini adalah ibu menyusui pada bayi usia 0-3 bulan membutuhkan proses dalam memperoleh suatu pengetahuan. Kebanyakan dari responden yang memiliki kemampuan kurang dalam mencegah regurgitasi dengan menyendawakan bayi sebelum pendidikan kesehatan (latihan) menyendawakan mengalami kecemasan dan ketakutan ketika menghadapi regurgitasi pada bayinya. Hal tersebut karena kurangnya pengetahuan, informasi yang diperoleh dari lingkungan di sekitarnya.

Bukan hanya faktor dari ibu menyui sendiri, namun bidan sebagai tenaga kesehatan sebaiknya memberikan pelayanan yang maksimal dalam memberikan konseling melalui asuhan kebidanan pada ibu nifas dimulai dari masa kehamilan mengenai cara mempersiapkan diri sebagai orang tua bagi bayinya.

\section{Kemampuan Motorik Ibu dalam Mencegah Regurgitasi pada Bayi Usia 0-3 Bulan Sesudah diberikan Pelatihan Menyendawakan}

Menurut Notoatmodjo (2013) praktik merupakan respon seseorang terhadap stimulus dalam bentuk tindakan (action) yang melibatkan aspek psikomotor. Adapun faktor-faktor yang mempengaruhi praktik menurut Lawrence green (2000) antara lain, faktor predisposisi meliputi pendidikan, ekonomi atau pendapatan, hubungan sosial, dan faktor pendukung meliputi lingkungan fisik, fasilitas kesehatan, sedangkan faktor penguat meliputi petugas kesehatan dan tokoh masyarakat.

Sesuai pendapat Notoatmodjo (2003), bahwa meningkatkan pengetahuan masyarakat juga melalui metode penyuluhan. Dengan pengetahuan seseorang yang bertambah akan merubah perilakunya. Karena itu, kemampuan motorik ibu dalam mencegah regurgitasi pada bayi usia 0-3 bulan dengan menyendawakan yang kurang ini disebabkan karena ibu belum pernah mendapatkan pelatihan tentang cara mencegah regurgitasi dengan cara menyendawakan sebelumnya. Melalui pendidikan kesehatan (latihan) menyendawakan yang telah dilakukan menunjukan adanya peningkatan kemampuan responden menjadi kemampuan cukup dalam mencegah regurgitasi pada bayi usia 0-3 bulan dengan menyendawakan.

Pengetahuan adalah hasil pengindraan manusia, atau hasil tahu seseorang terhadap objek melalui indera yang dimilikinya. Dengan sendirinya, pada waktu penginderaan sampai menghasilkan pengetahuan tersebut sangat dipengaruhi oleh intensitas perhatian dan persepsi terhadap obyek sesuai pendapat Notoatmodjo (2010) bahwa sebagian besar pengetahuan seseorang diperoleh melalui indera pendengaran (telinga) dan indera penglihatan (mata). Dalam penelitian ini, responden telah diberikan pendidikan kesehatan berupa pelatihan mencegah regurgitasi pada bayi usia 0-3 bulan dengan menyendawakan diikuti gerakan secara secara langsung ditirukan oleh responden, serta jika ada kekeliruan dapat langsung dilakukan pembetulan oleh peneliti. Dengan demikian ibu dapat lebih mudah dalam memahami dan mencegah regurgitasi dengan menyendawakan bayi.

Pengalaman akan menghasilkan pemahaman yang berbeda bagi setiap individu. Pengalaman tersebut tentunya berkaitan dengan pengetahuan. Seperti yang disampaikan oleh Sasongko (2010) bahwa seseorang yang memiliki banyak pengalaman, akan menambah pengetahuan dan keterampilan. Dalam penelitian ini responden telah menerima pendidikan kesehatan berupa pelatihan mencegah regurgitasi dengan 
menyendawakan bayi. Jadi bila tidak dilakukan pendidikan kesehatan berupa pelatihan secara langsung, responden tidak dapat menyendawakan bayi dengan baik.

\section{Perbedaan Kemampuan Motorik Ibu dalam Mencegah Regurgitasi pada Bayi Usia 0-3 Bulan Sebelum dan Sesudah diberikan Pelatihan Menyendawakan}

Sesuai analisis data, maka didapatkan adanya perbedaan kemampuan motorik ibu dalam mencegah regurgitasi pada bayi usia 0- 3 bulan sebelum dan sesudah pendidikan kesehatan (latihan) menyendawakan di Wilayah Kerja Puskesmas Ngadiluwih Kabupaten Kediri. Hal ini terbukti dari harga $\mathrm{z}$ hitung yaitu $5,302>\mathrm{z}$ tabel $(1,96)$ Hal ini diperkuat dari hasil tabulasi pada diagram 5 dapat diketahui bahwa sebagian besar dari responden memiliki kemampuan motorik kurang dalam mencegah regurgitasi sebelum dilakukan pendidikan kesehatan (latihan) menyendawakan yaitu 26 responden $(70,2 \%)$ dan setelah diberikan pendidikan kesehatan (latihan) menyendawakan lebih dari setengah responden memiliki kemampuan motorik cukup dalam mencegah regurgitasi, yaitu 29 responden $(78,3 \%)$. Dengan demikian maka Ho ditolak dan $\mathrm{H} 1$ diterima yang berarti ada perbedaan kemampuan motorik ibu dalam mencegah regurgitasi pada bayi usia 0- 3 bulan sebelum dan sesudah pendidikan kesehatan (latihan) menyendawakan di Wilayah Kerja Puskesmas Ngadiluwih Kabupaten Kediri.

Penelitiaan dengan judul Pengaruh Penyuluhan Kesehatan Terhadap Tingkat Pengetahuan Ibu Menyususi Bayi Usia 06 Bulan tentang Regurgitasi di Desa Glagah Kecamatan Pakuniran Kabupaten Probolinggo oleh Ifkan Maulana, dengan uji t-test menunjukan hasil bahwa terdapat Pengaruh Penyuluhan Kesehatan Terhadap Tingkat Pengetahuan Ibu Menyususi Bayi Usia 0- 6 Bulan tentang Regurgitasi di Desa Glagah Kecamatan Pakuniran Kabupaten Probolinggo. Hal ini menunjukan bahwa pengetahuan yang diberikan kepada seorang individu melalui pendidikan kesehatan mampu meningkatkan pengetahuan, pemahan dan menjadika keterampilan pada individu tersebut. Seperti yang diungkapkan oelh Notoatmodjo (2013) salah satu bentuk usaha yang dapat membantu individu dalam meningkatkan kemampuan untuk mencapai derajat kesehatan yang lebih baik ialah dengan pendidikan kesehatan.
Heri
DJ Maulana

(2011)

mengemukakan bahwa seseorang dapat dikatakan belajar apabila di dalam dirinya terjadi perubahan, dari tidak tahu menjadi tahu, dari tidak dapat mengerjakan menjadi dapat mengerjakan sesuatu.

Hal serupa juga disampaikan oleh Lawrence Green dalam Notoatmodjo (2003), yaitu terbentuknya suatu perilaku salah satunya dipengaruhi oleh faktorfaktor pemungkin (ketersediaan sumbersumber dan fasilitas). Penyedia layanan kesehatan dan tenaga kesehatan di dalammnya melalui pendidikan kesehatan berupa pelatihan, penyuluhan di bidang kesehatan memudahkan seorang individu dalam menerima informasi baru,

Maka, seorang ibu akan mampu mengaplikasikan pengetahuannya melalui pendidikan kesehatan yang teah diberikan berupa pelatihan tentang cara mencegah regurgitasi dalam hal menyendawakan bayi usia 0-3 bulan selama 30 menit melalui proses tanya jawab, demonstrasi dan redemonstrasi diikuti pembagian leaflet.

Penelitian tentang Pengaruh pendidikan kesehatan (latihan) senam nifas terhadap kemampuan melaksanakan senam nifas pada ibu post partum di Wilayah Kerja Polindes Satriyan Kabupaten Blitar oleh Evilia Dian Kartika (2008) dengan uji t-test, $\alpha \quad 0,05$ memberikan hasil ada pengaruh pendidikan kesehatan (latihan) senam nifas terhadap kemampuan melaksanakan senam nifas pada ibu post partum. Hal ini disebabkan peneliti telah memberikan latihan senam nifas diikuti gerakan secara 
langsung. Dengan demikian ibu lebih mudah memahami dan mengerjakan senam nifas dengan baik.

Pendidikan berupa pelatihan berarti bimbingan yang diberikan seseorang kepada orang lain agar dapat memahami sesuatu hal. Pada dasarnya, setiap asuhan bayi memerlukan keterlibatan orang tua mencakup keterampilan dan pengetahuan dalam perawatan bayi. Ibu yang melewatkan untuk menyendawakan bayinya setelah disusui, tentu saja bukan karena faktor kelalaian, melainkan karena faktor ketidaktahuan. Oleh sebab itu perlunya meningkatkan pengetahuan ibu terhadap cara dalam merawat bayinya di usia dini khususnya dalam mencegah regurgitasi melalui pendidikan kesehatan berupa pelatihan menyendawakan.

Penelitian Rona Riasma (2010) tentang pengaruh pendidikan kesehatan tentang pijat bayi terhadap praktik pijat bayi di Polindes Harapan Bunda Sukoharjo dengan uji t-test, $\alpha$ 0,05 menunjukkan hasil bahwa ada pengaruh pendidikan kesehatan tentang pijat bayi terhadap praktik pijat bayi. Hal ini sesuai dengan teori bahwa praktik mempunyai beberapa tingkatan yaitu dimulai dari persepsi, respon terpimpin yaitu dapat melakukan sesuatu sesuai dengan urutan yang benar dan sesuai dengan contoh, mekanisme, dan adopsi yaitu suatu praktik yang sudah berkembang dengan baik (Notoatmodjo, 2003) yang diperoleh melalui pendidikan kesehatan tentang pijat bayi.

Peningkatan kemampuan seseorang adalah karena praktik dipengaruhi oleh predisposisi yaitu pengetahuan. Setelah ibu menerima pendidikan kesehatan berupa pelatihan menyendawakan, ibu akan menerima informasi baru kemudian mengadakan penilaian terhadap apa yang diketahui dan memberikan respon batin dalam bentuk sikap dalam mencegah regurgitasi dengan menyendawakan bayi.

Peningkatan kemampuan motorik ibu dalam menyendawakan bayi dari yang semula berada dalam kategori kemampuan kurang menjadi kemampuan cukup merupakan hasil dari pemberian pendidikan kesehatan berupa latihan menyendawakan yang telah diajarkan oleh peneliti mealalui demonstrasi secara langsung dengan gerakan terbimbing. Apabila terdapat kesalahan peneliti dapat secara langsung membetulkan kesalahan dari cara yang dilakukan oleh responden. Pembagian leaflet tentang cara dalam menyendawakan bayi juga pelaksanaan redemonstrasi merupakan salah satu usaha dalam meningktakan kemampuan responden. Kegiatan menyendawakan memang sesuatu yang sepele dan sederhana, namun ibu yang telah melewatkan menyendawakan bayinya setelah proses menyusui bukan hanya karena faktor kelalaian tapi juga ketidaktahuan mereka akan pentingnya menyendawakan bayi. Sesuai dengan pendapat Mubarak (2007) bahwa proses pemberian pendidikan kesehatan tidak hanya bertujuan untuk memberikan informasi baru tetapi juga bertujuan untuk memberikan motivasi agar seseorang mampu melaksanakan perilaku secara tepat.

Pengetahuan responden tentang cara mencegah regurgitasi dengan menyendawakan merupakan informasi baru yang ternyata mampu meningkatkan kemampuan ibu dalam mencegah regurgitasi dengan menyendawakan. Hal ini yang harus diperhatikan bahwa pendidikan kesehatan berupa latihan menyendawakan yang hanya diberikan satu kali, akan cenderung berhenti begitu saja dan bahkan tidak ada kelanjutannya, akhirnya hanya akan berpengaruh pada saat itu saja. Hal ini tentunya tidak dapat berjalan sesuai dengan harapan, untuk itu pendidikan kesehatan berupa latihan menyendawakan harus tetap dilaksanakan oleh tenaga kesehatana tentu saja tidak lepas dari peran seorang bidan. Notoatmodjo (2008) mengungkapkan bahwa pendidikan kesehatan adalah proses yang berkelanjutan dan dilaksanakan secara terus menerus agar 
masyarakat dapat melaksanankan perilaku hidup sehat secara mandiri.

\section{Kesimpulan}

1. Sebagian besar responden memiliki kemampuan kurang dalam mencegah regurgitasi pada bayi usia 0 - 3 bulan sebelum dilakukan pendidikan kesehatan (latihan) menyendawakan.

2. Sebagian besar responden memiliki kemampuan cukup dalam mencegah regurgitasi pada bayi usia 0 - 3 bulan setelah dilakukan pendidikan kesehatan pendidikan kesehatan (latihan) menyendawakan.

3. Ada perbedaan kemampuan motorik ibu dalam mencegah regurgitasi pada bayi usia 0 - 3 bulan sebelum dan sesudah pendidikan kesehatan (latihan) menyendawakan di Wilayah Kerja Puskesmas Ngadiluwih Kabupaten Kediri.

\section{Saran}

1. Bagi Peneliti Selanjutnya

Diharapkan dapat mengembangkan kajian penelitian ini lebih luas, penyampaikan pendidikan kesehatan dengan waktu dan tempat yang lebih efisien sehingga mampu mendapatkan hasil yang diharapkan secara optimal.

2. Bagi Tenaga Kesehatan

Bagi tenaga kesehatan diharapkan penelitian ini mampu menjadikan pemahaman bahwa sebagai tenaga kesehatan memiliki tanggung jawab berkesinambungan pada asuhan kebidanan pada ibu sejak hamil, persalinan, hingga menyususi sebagai orang terdekat bagi bayi nya. Sehingga sebagai seorang ibu mampu merawat bayinya secara mandiri dengan cara yang tepat dan benar.

3. Bagi Institusi Pendidikan

Sebagai lembaga pencetak generasi penerus bangsa diharapkan mampu memberikan pembelajaran bagi anak didiknya terutama tentang perawatan bayi baru lahir sebagai bekal dilapangan agar menjadi tenaga kesehatan yang menguasai teori dengan baik dan mampu mengaplikasikannya secara tepat.

\section{Daftar Pustaka}

Alpers, Ann. 2006. Buku Ajar Pediatri Rudolph. Jakarta: EGC

Arief. 2009. Neonatus dan Asuhan Keperawatan Anak. Yogyakarta: Nuha Medika.

Bahiyatun. 2009. Buku Ajar Asuhan Kebidanan Nifas Normal. Jakarta: EGC.

Hamilton, Persis Mary. 2011. Dasardasar keperawatan maternitas. Jakarta :EGC.

Heri D.J Maulana, 2009. Promosi Kesehatan. Jakarta: EGC.

Hermawan, Asep Herry. 2010. Pengembangan Kurikulum dan Pembelajaran. Jakarta: Universitas Terbuka.

Hidayat, A. Aziz Alimul (2007). Metode penelitian kebidanan dan teknik analisis data. Jakarta :Salembamedika.

Ieneke, S. 2002. 100 Pertanyaan mengenai bayi.Jakarta: Pustaka Sinar Harapan.

Kelly, Paula. 2010. Asuhan Neonatus dan Bayi. Jakarta: EGC

Lissauer, Tom. 2009. At A Glance Neonatologi. Jakarta: Erlangga

Maryunani, Anik. 2010. Ilmu Kesehatan Anak dalam Kebidanan. Jakarta: Trans Info Media.

Mubarak, Bambang Adi Santoso, Khoirul Rozikin dan SitiPatonah. 2006. Ilmu 
Keperawatan Komunitas. Jakarta: Erlangga.

National Safety Council. 2007. Pertolongan Pertama dan RJP Pada Anak.

Jakarta: Arcan.

Nursalam. (2011). Konsep dan Penerapan Metodologi Penelitian Ilmu Keperawatan: Pedoman Skripsi, Tesis dan Instrumen Penelitian. Jakarta : Salemba Medika. .(2008). Konsep dan Penerapan Metodologi Penelitian Ilmu Keperawatan: Pedoman Skripsi, Tesis dan Instrumen Penelitian. Jakarta: Salemba Medika.

(2003). Konsep dan Penerapan Metodologi Penelitian Ilmu Keperawatan: Pedoman Skripsi, Tesis dan Instrumen Penelitian. Jakarta: Salemba Medika.

Notoatmodjo, S. 2010. Metodelogi Penelitian Kesehatan. Jakarta: Rineka Cipta.

Rochmah, KM. 2011. Asuhan Neonatus, Bayi dan Balita. Jakarta: EGC.

SanjayaWina, 2008. StrategiPembelajaranBerorientasiSt andar Proses Pendidikan. Jakarta: Prenada Media Group.

Sasongko, Bagus. (2010). Pengetahuan Ibu Nifas Tentang Perawatan Payudara di BPS Farida Desa Kedungwungu Kecamatan Tegaldlimo Kabupaten Banyuwangi. Diakses 2 Mei $2010<\mathrm{http} /$ /bejocommunity.blogspot .com>

Sodikin.2011. AsuhanKeperawatanAnak: GangguanSistem Gastrointestinal
danHepatobilier.

Jakarta:

SalembaMedika.

Soekidjo, Notoatmodjo. 2010. Metodologi Penelitian Kesehatan. Jakarta: Rineka Cipta.

Subekti, Budhi Nike. 2007. Buku Saku Managemen Masalah Bayi Baru Lahir. Jakarta: EGC.

Sugiyono, Dr. 2011. Metode penelitian kuantitatif kualitatif dan $r \& d$. Bandung: Alfabeta.

Sujarwo, Rony. 2012. Faktor-faktor yang memepengaruhi pengetahuan rendah. Diakses 8 juli 2011. http://id.shvoong.com/sociaksciences/education/2183789-faktorfaktor-yang-mempengaruhipengetahuan/

Sunardi. 2008. Ayah, Beri Aku ASI. Solo: Aqwamedika.

Suliha, Herawati, Sumiati. 2002. Pendidikan Kesehatan dalam Keperawatan.Jakarta: EGC.

Surya, HM. 2007. Kapita Selekta Kependidikan SD. Jakarta: Universitas Terbuka

Wong... [et al.]; alihbahasa, AgusSutarna, NetiJuniarti, H.Y.Kuncara.Buku Ajar Keperawatan Pediatrik Wong, Ed. 6, Vol. 1. Jakarta: EGC. 2008.

Yeyeh Ai Rukiyah. 2012.Asuhan Neonatus Bayi dan Anak Balita. Jakarta: Trans Info Media 